\title{
Manajemen Periklanan Cafe La Fellas dalam Membangun Brand
}

\author{
Image \\ Clara Yulianita dan Daniel Tamburian, \\ clarayulianita@gmail.com,danielt@fikom.untar.ac.id \\ Fakultas Ilmu Komunikasi Universitas Tarumanagara
}

\begin{abstract}
The development of the cafe business in Indonesia is currently very rapid. Many emerging business people who open a cafe business with various concepts or ideas that are made to attract customers from various walks of life. In this study aims to find out the advertising management of cafe La Fellas in building a brand image. The theory used in this study is advertising management theory and brand image theory. This study uses descriptive qualitative methods. Data obtained is by unstructured interviews and observations. The interviewees in this study were cafe owners, cafe managers and cafe consumers. The results of the study show that the advertising media used by cafe La Fellas is by using Instagram social media, working together with the Zomato and Pergikuliner application because it is very easy to use and free. Then it was greatly helped by food blogger services that advertise this cafe food.
\end{abstract}

Keywords:Periklanan, Manajemen Periklanan, Brand Image

\begin{abstract}
Abstrak
Perkembangan bisnis cafe di Indonesia saat ini sangat pesat. Banyak bermunculan para pelaku bisnis yang banyak membuka usaha cafe dengan adanya konsep atau ide-ide yang ingin dibua semenarik mungkin. Dalam penelitian ini bertujuan untuk mengetahui manajemen periklanan cafe La Fellas dalam membangun brand image. Pada penelitian ini penulis menggunakan teori manajemen periklanan dan teori brand image. Penelitian ini menggunakan metode kualitatif deskriptif. Data yang diperoleh yaitu dengan wawancara tidak terstruktur dan observasi. Narasumber yang diwawancarai pada penelitian ini adalah pemilik cafe, manajer cafe dan konsumen cafe. Hasil penelitian menunjukkan bahwa media periklanan yang digunakan oleh cafe La Fellas yaitu dengan menggunakan media sosial instagram, bekerja sama dengan aplikasi zomato dan pergikuliner karena sangat mudah digunakan dan gratis. Kemudian sangat terbantu oleh jasa food blogger yang mengiklankan makanan cafe ini.
\end{abstract}

Kata Kunci: Periklanan, Manajemen Periklanan, Brand Image

\section{Pendahuluan}

Perkembangan bisnis cafe di Indonesia saat ini sangat pesat. Banyak bermunculan para pelaku bisnis yang banyak membuka usaha cafe dengan adanya berbagai konsep atau ide-ide yang dibuat untuk memikat pelanggan dari berbagai kalangan. Setiap usaha pasti akan mengalami banyak rintangan oleh para pesaing lainnya. Persaingan bisnis cafe membuat persaingan antar pelaku bisnis semakin ketat, sehingga mengakibatkan para pelaku bisnis harus berpikir lebih kreatif untuk menciptakan konsep yang berbeda dari cafe-cafe yang lain. 
Cafe merupakan salah satu tempat untuk melepaskan penat dari segala aktivitas sehari-hari yang membuat tingkat stres dan kepenatan masyarakat semakin tinggi. Berbeda dengan dulu, cafe hanyalah sebagai tempat untuk makan dan minum, tetapi sekarang cafe dapat dijadikan sebagai tempat untuk masyarakat yang senang berkumpul, bersantai dan berbincang-bincang dengan teman, menjadikan cafe sebagai tempat yang nyaman untuk bersosialisasi, mengerjakan tugas, tempat untuk berdiskusi, dan dapat juga menghilangkanjenuhpara anggota karyawan kantor. Bahkan pekerja kantoran sering menjadikan cafe sebagai tempat untuk meeting dengan rekan kerja bisnisnya.

Namun selain itu ada beberapa hal menarik yang dimiliki cafe La Fellas. CafeLa Fellas tisak hanya sekedar tempat untuk makan dan minum tetapi mempunyai tempat workspace yang dapat mengundang orang kantor serta anak-anak muda yang ingin mengadakan acara dan lebih mensuport orang-orang yang ingin berkegiatan meeting dan mengerjakan tugas dengan meja yang lebih nyaman untuk mengerjakannya.

Persaingan bisnis di bidang periklanan begitu ketat dan kompetitif. Kemajuan teknologi saat ini membuat bisnis periklanan semakin berkembang dan maju untuk itu diperlukan adanya manajemen yang baik. Manajemen periklanan mempunyai kegunaan dalam dunia periklanan, karena manajemen merupakan instrumen utama untuk mencapai tujuan organisasi yang telah ditetapkan dan merupakan suatu sistem yang berfungsi untuk mengatur aktifitas seluruh elemen dalam suatu lembaga.yang meliputi proses perencanaan, pengorganisasian, penganggaran, kepemimpinan, dan pengendalian.

Periklanan merupakan saah satu bagian industri modern. Saat ini kehidupan dunia modern sangat bergantung pada iklan. Persaingan iklan di era ini antar brand semakin sengit dikarenakan setiap brand ingin mengekspansi dan mendominasi pasar dan munculnya brand-brand baru, karena pada dasarnya sebuah brand atau perusahaan ada pada penjualan, iklan dibutuhkan untuk meningkatkan awareness dan meningkatkan penjualan. Periklanan merupakan hasil dan ilmu. Seninya itu berasal dari pesan penulisan, perencanaan, dan produksi pesan yang menyenangkan. Sedangkan ilmunya berasal dari pemikiran dan perencanaan strategis, termasuk riset (Lee and Johnson, 2007). Selain itu periklanan juga memiliki peran penting lain di masyarakat demokrasi yakni menjadi sumber pendapatan utama bagi koran, majalah, televisi, dan radio. Tanpa iklan, tidak akan ada media yang menjadi rujukan orang untuk mendapat informasi, hiburan, dan pertukaran gagasan tentang isu-isu publik (Vivian, 2008).

Menurut Kotler (Hermawan, 2012) citra merek (brand image) adalah persepsi atau keyakinan yang dilakukan oleh konsumen yang tercermin dalam asosiasi yang terjadi dalam memori konsumen. Brand image dalam dunia periklanan menjadi salah satu hal yang sangat penting dilihat oleh pembeli. Brand image bukan hanya sekedar nama atau logo dari suatu produk atau perusahaan, tetapi juga merupakan citra atau persepsi seseorang tentang suatu produk atau perusahaan. Dengan demikian brand image adalah sekumpulan dari asosiasi mengenai suatu merek yang disimpan dalam ingatan pembeli. 


\section{Metode Penelitian}

Jenis penellitian yang dilakukan oleh penulis adalah penelitian kualittatif. Penelitian kualitatif merupakan sebuah penelitian yang bermaksud untuk memahami suatu fenomena tentang apa yang dapat dialami oleh subjek penelitian misalnya seperti tindakan, motivasi, persepsi, dan perilaku. Secara holistik, dan dengan cara deskripsi dalam bentukbahasa dan kata-kata, pada suatu konteks khusus yang alamiah dan dengan memanfaatkan berbagai metode alamiah (Moleong, 2012). Metode penelitian yang penulis gunakan dalam penelitian ini adalah menggunakan metode deskriptif studi kasus. Studi kasus merupakan hasil penyelidikan empiris dimana menginvestigasi sebuah fenomena kontemporer didalam konteks kehidupan nyata, khususnya ketika batas antara fenomena dan konteks tidak begitu jelas, (Yin, 2011).

Pada penelitian ini subjeknya adalah pemilik dan konsumen cafe La Fellas.Sedangkan objeknya adalah manajemen periklanancafe La Fellas. Metode pengumpulan data yang digunakan penulis yaitu wawancara, observasi, dokumentasi, dan studi kepustakaan. Teknik analisa data yang digunakan dalam penelitian ini adalah penyajian data, reduksi data, dan kesimpulan atau verifikasi. Selanjutnya dalam penelitian ini teknik pemeriksaan keabsahan data yang penulis gunakan adalah triangulasi data. Menurut (Moleong, 2012), triangulasi merupakan teknik pemeriksaan keabsahan data diaman memanfaatkan sesuatu yang ada. Di luar data sebagai keperluan pengecekan dan sebagai pembanding terhadap data tersebut. Teknik triangulasi sering dipakai adalah pemeriksaan melalui sumber-sumber lainnya. Dalam penelitian ini penulis menggunakan triangulasi sumber, yaitu dengan melakukan wawancara dan membandingkan hasil wawancara dengan hasil observasi serta dokumen yang sudah diteliti.

\section{Hasil Temuan dan Diskusi}

\section{Manajemen Periklanan}

Menurut Kotler dan Keller (2012) dalam buku Komunikasi Pemasaran Terpadu Priansa, (2017) menyatakan bahwa dalam program periklanan, manajer periklanan selalu memulai dengan mengidentifikasi pasar sasaran dam motif pembelian. Untuk dapat menghasilkan iklan yang efektif, maka perlu untuk memperhatikan lima keputusan utama dalam manajemen iklan yang kemudian disebut sebagai $5 \mathrm{M}$, yaitu:

1. Penetapan tujuan periklanan (missions)

Tujuan periklanan berkaitan dengan komunikasi yang spesifik, untuk dilaksanakan berdasarkan audiens spesifik dalam periode waktu yang tepat. Dapat diperjelasdengan adanya tujuan primer yaitu dapat memberikan informasi, membujuk, atau meningkatkan. Tujuan iklan yang ingin disampaikan oleh cafe La Fellas sudah tepat sasaran. Cafe ini bukan hanya ingin mendapatkan keuntungan pada bisnis tetapi mereka juga berharap agar para calon konsumen yang datang dapat merasa nyaman dan dapat menikmati suasana cafe yang nyaman didukung dengan dekorasi yang ada. Orang yang datang ke cafe ini tidak hanya sekedar makan dan minum tetapi mereka juga bisa membuat komunitas di cafe ini bisa meeting, kerja kelompok, dan mengadakan sebuah acara. 


\section{Menetapkan anggaran periklanan (money)}

Perusahaan dapat menetapkan anggaran iklan untuk setiap produk. Peran iklan mempengaruhi permintaan suatu produk. Perusahaan ingin mengeluarkan jumlah yang diperlukan untuk mencapai sasaran penjualan. Anggaran biaya yang dikeluarkan cafe La Fellas tidak teralu banyak karena memanfaatkan media sosial instagram yang sangat mudah dan gratis. Cafe La Fellas hanya turut berpartisipasi dengan membayar jasa food blogger untuk mengiklankan menu makanan yaitu Rp. 500.000 untuk 3 post foto.

3. Menentukan pesan periklanan (message)

Pesan produk dapat diputuskan sebagai bagian dari pengembangan konsep produksi, ia menunjukkan manfaat utama yang ditawarkan oleh merek tersebut. Pesan yangdisampaikan untuk konsumen cafe la Fellas yaitu adanya berbagai macam makanan--makanan dan minuman-minuman, pesan ini disampaikan kepada calonkonsumen agar dapat mengetahui apa saja makanan dam minuman yang akan dijual oleh cafe La Fellas ini.

4. Memilih media periklanan (media)

Pemilihan media periklanan bergantung pada tempat yang dituju, konsumen yang diharapkan, daya tarik iklan yang digunakan oleh media-media tersebut, fasilitas yang diberikan oleh media-media tersebut dalam hal biaya. Dalam melakukan suatu kegiatan periklanan peranan media sangat penting untuk mencapai tujuan periklanan suatu produk atau jasa yang sedang dijalankan oleh pelaku bisnis. Sekarang ini banyak sekali media baru yang dimanfaatkan oleh pelaku bisnis untuk mengiklankan produk atau jasa yang ditawarkannya oleh karena itu cafe La Fellas memanfaatkan peluang yang sama demi memperkenalkan produk yang mereka tawarkan. Media yang digunakan oleh cafe La Fellas yaitu media sosial instagram, bekerjasama dengan aplikasi zomato dan pergikuliner. Selain itucafe La Fellas juga memanfaatkan salah satu akun instagram food blogger terkenal yaitu @mrkulinerjkt.

5. Mengevaluasi periklanan (measurement)

Program periklanan dapat dievaluasi dendan cara reguler untuk mengetahui pengaruhnya terhadap komunikasi dan penjualan. Evaluasi dapat dilakukan untuk melihat bagaimana respon konsumen pada kualitas serta pelayanan yang disediakan oleh cafe La Fellas dengan melihat jumlah pelanggan setiap bulannya naik atau tidak, maksimal atau tidak promosi yang dijalankan di media sosial. Dalam evaluasi ini menjadi pelajaran dan referensi bagi cafe La Fellas dalam melakukan kegiatan promosi kedepannnya. Apabila pelanggan setiap bulannya bertambah maka respon yang didapatkan baik begitu pun apabila pelanggan menurun berarti respon yang didapatkan kurang baik maka akan menjadi pelajaran agar dapat memperbaiki lebih baik lagi.

\section{Brand Image}

Menurut Kotler dan Keller (2013) dalam buku Priansa (2017), menyatakan bahwa citra merek adalah respons konsumen pada keseluruhan penawaran yang diberikan oleh perusahaan. Citra tersebut dapat berhubungan dengan arsitektur, nama bisnis,variasi dari produk, ideologi,tradisi, dan kesan pada kualitas komunikasi yang dilakukan oleh para karyawan saat interaksi dengan klien perusahaan. Citra merek tersebut diukur dengan menggunakan dimensi, yaitu: 


\section{Kepribadian (personality)}

Semua karakteristik yang dapat dipahami masyarakat luas, seperti dapat dipercaya dan mempunyai tanggung jawab sosial. Cafe La Fellas mempunyai karakteristik konsumen yang datang kebanyakan karyawan kantor dan anak sekolahan. Karena lokasi dekat dengan kantor dan sekolahan.

\section{Reputasi (reputation)}

Reputasi adalah hasil opini dari masyarakat mengenai perusahaan tertentu. Reputasi terbagi atas dua yakni reputasi yang baik dan reputasi yang buruk. Reputasi yang dibagun oleh cafe La Fellas adalah mempunyai reputasi yang baik dimata konsumen. Sampai saat ini cafe La Fellas dipercayai oleh masyarakat sebagai salah satu tempat nongkong untuk menghilangkan jenuh dan stress.

\section{Nilai-nilai (value)}

Dalam hal ini, konsumen menilai secara langsung bagaimana produk dan layanan yang mereka dapatkan dari suatu merek yang digunakan. Cafe La Fellas berhasil dalam membangun nilai-nilai yang baik dimata konsumen. Menurut konsumen pelayanan yang diberikan cafeLa Fellas sangat baik dan ramah serta cepat dan cekatan dalam memasak dan mengantar makanan pesenan mereka.

4. Identitas perusahaan (corporate identity)

Bagian-bagian yang mengubah penilaian masyarakat terhadap perusahaan. Desain logo yang digunakan cafe La Fellas adalah desain logo yang minimalis hanya dengan menggunakan warna hitam dan putih. Dinamakan cafe La Fellas karena asal mula nama La Fellas diambil dari bahasa spanyol fellas yang artinya teman. Kemudian dengan artinya teman membuat cafe ini menjadi bersahabat dengan para konsumen dan gampang diingat oleh konsumen.Konsep yang dinukanan cafe La Fellas adalah mengusung konsep industrial lengkap dengan adanya furniture yang digunakan untuk menambah kenyamanan pengunjung yang ingin bersantai di cafe ini.

\section{Kesimpulan}

Kesimpulan penelitian ini adalah media periklanan yang digunakan cafe La Fellas melaui media sosial instagram, karena banyak masyarakat yang menggunakan instagram pada zaman sekarang. Kemudian bekerja sama dengan aplikasi zomato dan pergikuliner. Disertai juga cafe La Fellas menggunakan food blogger sebagai cara untuk memperluas dan dapat diketahui oleh banyak masyarakat. Sehingga cafe La Fellas memiliki citra yang baik di mata konsumen.

\section{Ucapan Terima Kasih}

Ucapan terima kasih penulis berikan kepada Fakultas Ilmu Komunikasi Tarumanagara, dosen pembimbing H.H Daniel Tamburian, S.Sos., M. Si. dan kepada narasumber penulis Inne Dharmadi dan Dennis Dharmadi. Penulis juga mengucapkan banyak terima kasih kepada semua pihak yang telah membantu menyelesaikan laporan skripsi ini. 


\section{Daftar Pustaka}

Agus, Hermawan. (2012). Komunikasi Pemasaran. Jakarta: Erlangga.

Lee, Monle, and Johnson, Carla. (2007). Prinsip-Prinsip Pokok Periklanan Dalam Perspektif Global. Jakarta: Kencana.

Moleong, Lexy J. (2012). Metedologi Penelitian Kualitatif. Bandung: PT Remaja Rosdakarya.

Priansa, Donni Juni. (2017). Komunikasi Pemasaran Terpadu Pada Era Sosial Media. Bandung: Penerbit Pustaka Setia Bandung.

Vivian, John. (2008). Teori Komunikasi Massa,( Edisi 8). Jakarta: Kencana.

Yin, Robert K (2011). Studi Kasus Desain dan metode, Jakarta : Raja Grafindo Persada. 